\title{
Tırnak Batması Tedavisinde Topikal Anesteziklerin Etkinliği
}

\section{Efficacy of Topical Anesthetics in the Treatment of Ingrown Nail}

\author{
Fatma Gülru Erdoğan, Münevver Güven, Aysel Gürler
}

Ufuk Üniveristesi Tıp Fakültesi, Deri ve Zührevi Hastalıklar Anabilim Dalı, Ankara, Türkiye

\section{Özet}

Amaç: Tırnak batmasında konservatif yöntemlerin tercih edilme nedenlerinden biri lokal anestezi gibi ağıılı bir basamağın olmamasıdır. Bununla beraber tırnak batmasının kendisi ağrılı bir durumdur. Bazal ağıı düzeyi yüksek hastalarda uygulama yapmak oldukça zor olabilmektedir. Bu çalışmada şiddetli ağrısı olan tırnak batması şikayeti ile başvuran hastalarda topikal anestezik \%2,5 lidokain, $\% 2,5$ prilokain mikstürü ve $\% 20$ benzokain jelin bazal ağrı düzeyi, işlem sırası ve sonrasındaki ağrı üzerinde etkinliğini değerlendirmeyi amaçladık.

Gereç ve Yöntem: Çalışmaya tırnak batması şikayeti olan ve tırnak teli tedavisi planlanan 14-70 yaş aralığında 12'si erkek 17 'si kadın 29 hasta alındı. Hastalar tırnak batmasının evresinden bağımsız şekilde rastgele olarak lidokain-prilokain mikstürü ve benzokain jel uygulanan 2 gruba ayrıldı. Benzokain jel uygulamadan 10 dakika önce, lidokain-prilokain mikstürü uygulamadan 2 saat önce oklüzyonla uygulandı. Her iki grubun topikal anestezik öncesi, sonrası, işlem sırasında ve işlemden yarım saat sonraki ağrı düzeyleri sayısal ağrı ölçeğine göre değerlendirildi.

Bulgular: Her iki grubun topikal anestezik öncesi, sonrası, işlem sırası ve işlemden yarım saat sonraki ağrı değerleri arasında istatistiksel olarak fark tesbit edilmedi. Tırnak batmasının evresinden bağımsız olarak değerlendirildiğinde her iki grupta da topikal anestezik sonrası ve işlemden yarım saat sonraki ağrı değerlerinin topikal anestezik öncesi ağrı değerlerine göre istatistiksel olarak anlamlı derecede azaldığı saptandı. Her iki grupta da işlem sırasında ağrı değerleri topikal anestezik öncesi bazal değerlere benzer düzeye yükseldi. Tırnak batmasının evresine göre değerlendirildiğinde evre 2 ve 3 tırnak batması olan olgularda lidokain-prilokain mikstürü bazal ağrıyı anlamlı şekilde azaltmazken benzokain kullanan grupta anlamlı azalma saptandı.

Sonuç: Uygulama kolaylığı ve özelikle evre 2-3 tırnak batmalarındaki etkinliği nedeniyle \%20 benzokain jel tırnak batması olan hastalarda bazal ağrıyı hafifletmek ve konservatif uygulamaları yapmakda yardımcı olabilir. (Türkderm 2011; 45: 88-92) Anahtar Kelimeler: Tırnak batması, topikal anestezikler, benzokain, lidokain-prilokain

\section{Summary}

Background and Design: One of the reasons for preferring conservative methods for ingrown nails is lack of local anesthesia for the painful step. Moreover, ingrown nail is a painful condition per se. It may be very difficult to intervene patients with high basal pain levels. Here, we aimed to assess the efficacy of topical anesthetics ( $2.5 \%$ lidocaine, $2.5 \%$ prilocaine mixture and $20 \%$ benzocaine gel) by determining basal pain level and pain during and after manipulation in patients with severe pain who applied with ingrown nail complaint.

Material and Method: In this study, we included a total of 29 patients (12 male, 17 female) who had complaint of ingrown nail and for whom nail brace treatment was planned. The patients were divided randomly into two groups regardless of the stage of ingrown nail: with lidocain-prilocain mixture application and with benzocaine gel application. Benzocaine gel was applied 10 minutes before the procedure and lidocaine-prilocaine mixture was applied under occlusion, 2 hours prior to the procedure. Pain levels were evaluated on a numerical pain rating scale before and after topical anesthesia as well as during and half an hour after the procedure in both groups.

Yazışma Adresi/Address for Correspondence: Dr. Fatma Gülru Erdoğan, Mevlana Bulvarı No: 86-88 Balgat, 06520 Ankara, Türkiye Tel.: +90 3124466060 E-posta: gulruer@gmail.com Geliş Tarihi/Received: 18.07.2010 Kabul Tarihi/Accepted: 21.09.2010

Türkderm-Deri Hastalıkları ve Frengi Arşivi Dergisi, Galenos Yayınevi tarafından basılmıştır.

Turkderm-Archives of the Turkish Dermatology and Venerology, published by Galenos Publishing. 
Results: Statistical difference was not detected between the pain levels of the two groups before and after topical anesthesia and during and half an hour after the procedure. Regardless of the stage of ingrown nail, the pain levels after topical anesthesia and half an hour after procedure were found to decrease significantly compared to the levels before topical anesthesia in both groups. Pain levels of both groups increased during the procedure and were similar to the basal levels. Considering the stage of ingrown nail, while lidocaine-prilocaine mixture did not decrease pain significantly in the cases with stage 2-3, benzocaine did.

Conclusion: Due to ease of application and especially to efficacy in stage 2-3 ingrown nails, $20 \%$ benzocaine gel may help in decreasing basal pain and in applying conservative manipulations in patients with ingrown nails. (Turkderm 2011; 45: 88-92)

Key Words: Ingrown nails, topical anesthetics, benzocaine, lidocaine-prilocaine

\section{Giriş}

Tırnak batması; hastalar için ciddi rahatsızlık yaratan, sık karşılaşılan, ağrılı bir sağlık problemidir. Tırnak batmasında 3 evre tanımlanmaktadır. Evre 1 tırnak batmasında hafif eritem, ödem ve batan tırnak çevresinde ağrı, evre 2 de eritem ve ödeme ek olarak infeksiyon ve drenaj, evre 3 de ise bu bulgulara ek olarak lateral tırnak kenar hipertrofisi ve granülasyon dokusu mevcuttur ${ }^{1-4}$. Özellikle evre 2 ve 3 deki hastalarda ağrı herhangi bir işlem yapmayı zorlaştırabilmektedir. Tırnak batması tedavisinde uygulanan tedavi yöntemleri de uygulama sırasında hastanın ağrılı bölgesine dokunulmasını gerektirmekte ve bu da hastanın mevcut ağrısını arttırmaktadır. Tırnak batmasında tel gibi konservatif uygulamalarının tercih nedenlerinden biri, lokal anestezik kullanımına ihtiyaç duyulmamasıdır ${ }^{2}$. Işlemin kısa sürmesi, işlem sonrasında hastanın ağrı yakınmasında belirgin gerileme beklenmesi lokal anestezik kullanımını gereksiz kılmaktadır. Öte yandan tırnak batmasının kendisinin ağrılı bir durum olması ve bazı hastalarda ağrı toleransının daha düşük bulunması uygulamayı zorlaştırmaktadır. Bu hastalar genellikle dokunmakla bile şiddetli ağrı tarif etmekte olup ayrıca, genellikle injeksiyonlara da sıcak bakmamaktadır.

Anestezik kremler; uygulama kolaylığı ve uygulama sırasında ağrıya neden olmamaları nedeniyle plastik cerrahi, dermatoloji ve diş hekimliği alanlarında giderek daha yaygın olarak kullanılmaktadı ${ }^{5-7}$. Bu amaçla tüm dünyada en sık kullanılan maddeler prilokain-lidokain mikstürü ve benzokaindir $r^{5,6,8-10}$. Bu ajanların kan alınması, dijital sinir bloğu, injeksiyon ve çeşitli konservatif işlemlerden önce uygulanmasının hastanın ağrısını azaltarak kolaylaştırıcı etkileri olabildiğine dair yayınlar bulunmaktadır $\mathrm{r}^{6,8,11,12}$.

Bu nedenle; bu çalışmada tırnak batması nedeni ile tedavi amaçlı tırnak teli tedavisi uygulaması planlanan, bazal ağrı düzeyi herhangi bir işlem yapmayı engelleyecek kadar yüksek olan hastalarda, hastaların bazal ağrılarının hafifletilerek dokunmaya ve uygulamaya izin verir duruma gelebilmeleri için 2 farklı topikal anestezik madde olan prilokain-lidokain mikstürü ve benzokain uygulamasının etkinliğinin araştırılması ve etkinliklerinin karşılaştırılması amaçlanmıştır.

\section{Gereç ve Yöntem}

Çalışmaya tırnak batması şikayeti nedeniyle tırnak teli ile tedavi edilmesi planlanan dokunmakla belirgin ağrısı olan diyabeti, diyabetik nöropatisi, periferal vasküler hastalığı, hamilelik ya da laktasyon durumu olmayan evre 1,2 ya da 3 tırnak batması olan gönüllü hastalar alındı. Kriterlere uygun 14-70 yaş aralığında 12'si erkek 17 'si kadın olmak üzere 29 hasta çalışmaya dahil edildi. On altı hastanın yakınması tek taraflı,
13 ünün ise iki taraflı, tümü 1. ayak parmak tırnağındaydı. Çalışmaya gönüllü olarak katılan hastalar tırnak batması evresinden bağımsız, rastgele olarak topikal \%20 benzokain jel (Lollicaine jel) ya da \%2,5 lidokain, \%2,5 prilokain mikstürü (Emla krem) grubuna dahil edildi.

Hastalara ağrılarını değerlendirmeleri için sayısal ağrı ölçeği uygulandı. Bu ölçek ağrı şiddeti tanımını kolaylaştırdığı , puanlama ve kayıtta kolaylık sağladığı için çalışmalarda tercih edilmektedir ${ }^{13,14}$. Bu ölçekte hastanın ağrısı 0 ile 10 arasında numerik bir değer şeklinde tanımlanmaktadır. Sıfır hastanın ağrısının olmaması durumu iken 10 dayanılmaz ağrı olması şeklinde tanımlanmıştır. Hastalardan bu skalaya göre mevcut ağrılarını puanlamaları istendi.

Hastaların topikal anestezik krem ya da jel uygulamasından önce ağrı değerleri sayısal ölçek ile değerlendirildi ve kaydedildi. Evre 2 infeksiyonu olan hastalara uygulamadan en az 48 saat önce antibiyotik tedavisi başlandı. Hastalara herhangi bir ağrı kesici ya da antiiflamatuvar tedavi başlanmadı. Yalnızca granulasyon dokusu olan, infeksiyon bulgusu olmayan hastalara uygulama öncesi herhangi bir sistemik tedavi uygulanmadı. Ardından, benzokain grubundaki hastalara batan tırnağın olduğu parmağın tümünü kaplayacak şekilde pamuklu bir aplikatör yardımı ile 0,4 gram \%20 benzokain uygulandı ve 10 dakika sonra ağrı değerlendirilmesi tekrarlandı.

Diğer gruba ise batan tırnağın tüm kenarını kaplayacak şekilde 5 gram $\% 2,5$ lidokain, $\% 2,5$ prilokain mikstürü oklüzyon ile uygulandı ve 2 saat sonra ağrı değerlendirilmesi yapıldı. Her iki gruba lokal anestezik madde temizlendikten sonra tırnak teli uygulandı.

Hastaların topikal anestezik krem/jel uygulama öncesi, sonrası, tırnak teli uygulaması sırasında ve tırnak teli uygulamasından yarım saat sonra ağrı değerleri kaydedildi.

Çalışma verilerinin istatistiksel değerlendirmesi SPSS 15.0 versiyonu kullanılarak yapıldı.

\section{Bulgular}

Çalışmamıza alınan 17 evre 1 tırnak batması olgusunun 9'una benzokain, 8'ine lidokain-prilokain mikstürü, 25 evre 2 ve 3 tırnak batması olgusunun 16'sına benzokain, 9'una lidokainprilokain mikstürü uygulandı.

Hastaların bazal, topikal anestezik sonrası, işlem sırasında ve işlem sonrası verilerinin normal dağılıma uyup uymadığının değerlendirilmesi için Shapiro Wilk testi uygulandı ve verilerin normal dağılıma uymadığı saptandı.

Hastaların başvuru sırasında bazal ağrı değerleri karşılaştırıldığında benzokain ve lidokain-prilokain uygulanan hastalarda istatistiksel bir fark saptanmadı (p:0,887). Aynı gruplar topikal anestezik uygulaması sonrasında da ağrı düzeyleri bakımından farklı bulunmadı (p:0,471). 
Aynı şekilde grupların işlem sırasında $(p: 0,184)$ ve ișlemden yarım saat sonra (p:0,672) ağrı değerleri de birbirinden farklı değildi (Tablo 1).

Benzokain uygulanan hastalarda topikal anestezik sonrası değerlerde bazal değerlere göre anlamlı gerileme saptanmışken $(p<0,001)$, işlem sırasındaki ağrı bazal değerlerden farksızdı (p:0,238), işlemden yarım saat sonrasındaki değerler ise bazal değerlere göre anlamlı şekilde düşük bulundu $(p<0,001)$ (Tablo 2).

Lidokain-prilokain mikstürü uygulanan hastalarda topikal anestezik uygulaması sonrası ağrı değerleri bazal değerlere göre belirgin şekilde gerilemiş ( $p: 0,004)$, işlem sırasında ise bazal değerlere yakın değerlere ulaşmıştı (p:0,176), işlemden yarım saat sonra ise hastaların ağrı değerleri bazal değerlerden anlamlı şekilde düşük saptandı (p:0,006) (Tablo 2).

Evre 1 tırnak batması olan; infeksiyon ya da granülasyon do- kusu gelişimi olmayan hastalar değerlendirildiğinde, benzokain grubunun uygulama sonrası ağrı değerleri anlamlı şekilde düşük bulundu (p:0,012). Lidokain-prilokain mikstür grubunda da anlamlı azalma tesbit edildi (p:0,034). İşlem sırasında benzokain ( $p: 0,858)$ grubunun ağrı düzeyi bazal düzeye yükselirken, işlemden yarım saat sonra anlamlı şekilde gerilemiş bulundu (p:0,035). Aynı şekilde lidokain-prilokain grubunun da işlem sırasındaki ağrıları $(p: 0,4)$ bazal seviyeden farksız, işlemden yarım saat sonra değerleri ise gerilemiş bulundu $(0,012)$ (Tablo 3).

Sulantılı lezyonları olan evre 2 ve 3 hastalar değerlendirildiğinde, benzokain grubunun uygulama sonrası ağrı değerleri anlamlı şekilde düşük bulunmuşken (p:0,001), lidokain-prilokain grubunun ağrılarında gerileme saptanmadı (p:0,058). İşlem sırasında benzokain (p:0,167) grubunun ağrı düzeyi bazal düzeye yükselirken, işlemden yarım saat sonra anlamlı şekilde

Tablo 1. Evre 1,2,3 tüm hastalarda benzokain ve lidokain-prilokain uygulanan grupların değişik dönemlerde ağrı skorlarının karşılaştırılması

\begin{tabular}{|l|c|c|c|}
\hline \multirow{2}{*}{ Topikal anestezik öncesi } & & Ortanca (minumum-maksimum) & P (Mann Whitney U Testi) \\
\cline { 2 - 3 } & Benzokain & $5(0-10)$ & \multirow{2}{*}{ P:0,887 } \\
\cline { 2 - 3 } Topikal anestezik sonrası & Lidokain-prilokain & $5(0-10)$ & \multirow{2}{*}{$\mathrm{P}: 0,471$} \\
\cline { 2 - 3 } \multirow{2}{*}{ İşlem sırasında } & Lidokain-prilokain & $2(0-7)$ & \multirow{2}{*}{$\mathrm{P}: 0,184$} \\
\hline \multirow{2}{*}{ İşlemden yarım saat sonra } & Benzokain & $6(0-10)$ & \multirow{2}{*}{$\mathrm{P}: 0,672$} \\
\cline { 2 - 3 } & Lidokain-prilokain & $8(0-10)$ & $1(0-9)$ \\
\hline
\end{tabular}

Tablo 2. Evre 1,2,3 tüm hastalarda topikal anestezik ajanların etkinliklerinin değerlendirilmesi

\begin{tabular}{|c|c|c|c|c|}
\hline & \multicolumn{2}{|c|}{ Benzokain } & \multicolumn{2}{|l|}{ Lidokain-prilokain } \\
\hline & ortanca(minimum-maksimum) & $\begin{array}{c}\mathrm{P} \\
\text { (Wilcoxon testi) }\end{array}$ & ortanca (minimum-maksimum) & $\begin{array}{c}\text { P } \\
\text { (Wilcoxon testi) }\end{array}$ \\
\hline Topikal anestezik öncesi & $5(0-10)$ & \multirow{2}{*}{$<0,001 *$} & $5(1-10)$ & \multirow{2}{*}{$0,004^{*}$} \\
\hline Topikal anestezik sonrası & $2(0-7)$ & & $2(0-8)$ & \\
\hline Topikal anestezik öncesi & $5(0-10)$ & \multirow{2}{*}{0,238} & $5(1-10)$ & \multirow{2}{*}{0,176} \\
\hline İşlem sırasında & $6(0-10)$ & & $8(0-10)$ & \\
\hline Topikal anestezik öncesi & $5(1-10)$ & \multirow{2}{*}{$<0,001 *$} & $5(1-10)$ & \multirow{2}{*}{$0,006^{*}$} \\
\hline İşlemden yarım saat sonra & $1(0-9)$ & & $0(1-6)$ & \\
\hline
\end{tabular}

Tablo 3. Topikal anestezik ajanların tırnak batmasının evresine göre etkinliklerinin değerlendirilmesi

\begin{tabular}{|c|c|c|c|c|c|c|c|c|}
\hline & \multicolumn{4}{|c|}{ Benzokain } & \multicolumn{4}{|c|}{ Lidokain-prilokain } \\
\hline & \multicolumn{2}{|l|}{ Evre 1} & \multicolumn{2}{|l|}{ Evre 2-3 } & \multicolumn{2}{|l|}{ Evre 1} & \multicolumn{2}{|l|}{ Evre 2-3 } \\
\hline & $\begin{array}{l}\text { Ortanca } \\
\text { (minimum- } \\
\text { maksimum) }\end{array}$ & $\begin{array}{c}\text { P } \\
\text { Wilcoxon } \\
\text { testi }\end{array}$ & $\begin{array}{l}\text { Ortanca } \\
\text { (mininimum- } \\
\text { maksimum) }\end{array}$ & $\begin{array}{c}\mathrm{P} \\
\text { Wilcoxon } \\
\text { testi }\end{array}$ & $\begin{array}{l}\text { Ortanca } \\
\text { (minimum- } \\
\text { maksimum) }\end{array}$ & $\begin{array}{c}\mathrm{P} \\
\text { Wilcoxon } \\
\text { testi }\end{array}$ & & $\begin{array}{c}\mathrm{P} \\
\text { Wilcoxon } \\
\text { testi }\end{array}$ \\
\hline $\begin{array}{l}\text { Topikal } \\
\text { anestezik öncesi }\end{array}$ & $7(0-10)$ & \multirow[t]{2}{*}{$0,012^{*}$} & $4(0-10)$ & \multirow[t]{2}{*}{$0,001 *$} & \multirow{2}{*}{$\begin{array}{l}4,5(1-10) \\
2(0-8)\end{array}$} & \multirow[t]{2}{*}{$0,034^{*}$} & $5(1-9)$ & \multirow[t]{2}{*}{0,058} \\
\hline $\begin{array}{l}\text { Topikal } \\
\text { anestezik sonrası }\end{array}$ & $2(0-10)$ & & $1,5(0-7)$ & & & & $3(0-7)$ & \\
\hline $\begin{array}{l}\text { Topikal } \\
\text { anestezik öncesi }\end{array}$ & $7(0-10)$ & \multirow[t]{2}{*}{0,858} & $4(0-10)$ & \multirow[t]{2}{*}{0,167} & \multirow[t]{2}{*}{$4,5(1-10)$} & \multirow[t]{2}{*}{0,400} & $5(1-9)$ & \multirow[t]{2}{*}{0,292} \\
\hline İşlem sırasında & $6(2-9)$ & & $5,5(0-10)$ & & & & $8(0-10)$ & \\
\hline $\begin{array}{l}\text { Topikal } \\
\text { anestezik öncesi }\end{array}$ & $7(0-10)$ & \multirow[t]{2}{*}{$0,035^{*}$} & $4(0-10)$ & \multirow[t]{2}{*}{$0,002^{*}$} & \multirow[t]{2}{*}{$4,5(1-10)$} & \multirow[t]{2}{*}{$0,012^{*}$} & $5(1-9)$ & \multirow[t]{2}{*}{$0,023^{*}$} \\
\hline $\begin{array}{l}\text { İşlemden yarım } \\
\text { saat sonra }\end{array}$ & $1(0-9)$ & & $1(0-3)$ & & & & $5(1-9)$ & \\
\hline
\end{tabular}


gerilemiş bulundu ( $p: 0,002)$. Aynı şekilde lidokain-prilokain grubunun da işlem sırasındaki ağrıları $(p: 0,292)$ bazal seviyeden farksız, işlemden yarım saat sonra değerleri ise gerilemiş bulundu $(0,023)$ (Tablo 3$)$.

\section{Tartışma}

Tırnak batması tedavisinde tel gibi konservatif yöntemlerin tercih edilmesinin en önemli nedenlerinden biri iğne ve injeksiyon korkusudur. Yalnız çocuklarda değil erişkinlerde de yaygın olarak görülmekte olan bu durum, konservatif yöntemler için lokal anestezi uygulamasının tercih edilmeyen bir prosedür olmasına neden olmaktadır ${ }^{6}$.

Öte yandan ağrı, subjektif bir yakınma, kişisel bir algı olup, kişilik, kültür ve önceki tecrübelerden etkilenerek kişiden kişiye değişiklik gösterebilmektedir.

Bu çalışmaya iğne ve injeksiyon korkusu nedeniyle konservatif bir tedaviyi tercih eden ancak bazal ağrı yakınmaları çok şiddetli olduğundan palpasyonu bile tolere edemeyen hastalar dahil edildi. Dolayısıyla başka hasta gruplarıyla yapılacak uygulamaların sonuçları daha farklı düzeyde seyir gösterebilir. Bazal ağrı düzeylerine göre tüm evrelerdeki hastalar ele alındığında her iki topikal anestezik madde uygulaması da anlamlı şekilde ağrı hissinde gerilemeye neden olmuştur. Daha önce yapılan çeşitli çalışmalarda da her iki ajan hem deri yüzeyinde hem de mukozalarda etkinliği gösterilmiş ajanlardır6-10,15. Bununla birlikte uygulama sırasında her iki gruba aynı alanı içerecek şekilde krem/jel uygulanmış ancak benzokain jelin 0,4 gramlık bir kutusu ile etkinlik sağlanmış iken benzer etkinlik lidokain-prilokain mikstürünün 5 gramı ile elde edilmiştir. Bununla beraber $\% 2,5$ lidokain, $\% 2,5$ prilokain mikstürünün etkinlik süreleri deri yüzeyi için en az 60 dakika olarak belirlenmiş olup, 120 dakikada daha derin ve etkili bir anestezi sağladığı saptanmıştır ${ }^{8,0,11,15}$. Bu iki maddenin kimyasal özelliklerine bakıldığında lidokain-prilokain mikstürünün daha uzun sürede ve oklüzyon ile maksimum etkinliğe ulaştığı, dental amaçlarla uygulanan benzokain jelin ise mukozal yüzeylerde kısa sürede emilerek oklüzyon gerektirmeden etkili olabildiği bilinmektedir ${ }^{6}$.

Bu çalışmada maksimum etkinlik istenildiğinden lidokain-prilokain mikstürü ile uygulama süresini 120 dakika olarak belirlenmiş ve oklüzyon ile uygulama tercih edilmiştir. Bunun bir nedeni de intakt deri ile değil, şiddetli ağrısı olan bir bölgeye işlem uygulanmasıdır. Ağrıyı önlemekten çok mevcut ağrıyı azaltmak ya da kesmeye önem verilmiştir. Uygulama sonrasında hastaların ağrı yakınması tamamen kaybolmamakla beraber anlamlı gerileme göstermiştir. Ancak benzer bir gerilemenin 10 dakikalık benzokain jel uygulaması ile de elde edilebilmesi, ayrıca evre 2 ve 3 hastalarda sadece benzokainin ağrıyı anlamlı şekilde geriletebilmesi, bu ajanın hem kolay uygulanır hem de etkili olduğu şeklinde yorumlanabilir.

İşlem sırasında her iki grupta da ağrı şiddetinin baştaki ağrı düzeyine döndüğü görülmekle birlikte topikal anestezi hasta- ya ilk anda dokunmayı kolaylaştırmaktadır. Tel uygulaması sadece 1-2 dakika içinde bitmesi beklenen bir uygulama olduğundan topikal anestezi, şiddetli ağrısı olan ajite hastalarda bu işlemi yapabilme şansı verebilmektedir.

Yapılan çalışmalarda lidokain-prilokain mikstürünün bazı kısıtlamaları olduğu belirtilmiştir. Örneğin el içi ve ayak tabanından homojen olarak emilemediği, oral mukoza uygulamalarında uygulama bölgesinde kalmayıp etrafa dağıldığı belirtilmiş ve bunların etkinliğini etkileyen faktörler olduğu vurgulanmışıı?. Evre 2 ve 3 tırnak batmaları genellikle sulantılı olduğundan lezyon özellikleri söz konusu ajanın homojen emilimini engellemiş, öte yandan benzokain jel oklüzyonla uygulanmadığından normal ısıda uygulama bölgesinde daha stabil kalmış olabilir.

Lidokain-prilokain kremin tırnak batması için opere olacak hastalarda dijital blok öncesi normal deriye uygulanmasının infiltrasyondan kaynaklanan derin ağrıyı azaltmadığına, bunun nedeninin de yeterince derin emilememesi olduğuna dair yayınlar bulunmaktadır ${ }^{12}$. Bununla beraber bu çalışmada uygulama yapılan alan deri yüzeyi olduğundan evre 2 ve 3 lezyonlarda etkisiz kalması bu nedene bağlanamaz.

İşlemden yarım saat sonra ölçülen ağrı değerlerine bakıldığında ağrının topikal anestezik uygulanması öncesine göre belirgin azalma gösterdiği görülmüştür. Bu azalma hem anestezik maddelerin etkinliğinin devam etmesine hem de tırnak telinin tırnağı batmakta olduğu yerden yükselterek iritasyonu gidermesine bağlanabilir. Farmakolojik olarak hem benzokainin hem de lidokain-prilokain mikstürünün uygulama sonrasında 30 dakika etkili olduğu belirtilmiştir ${ }^{7,16,17}$.

Hastalarda herhangi bir yan etki saptanmamıştır. Lidokainprilokain mikstürünün uygulama bölgesinde beyazlaşma, eritem, ödem, nadiren kontakt dermatit gelişimi yapabildiği, 3 aydan küçük çocuklarda methemoglobinemi gibi yan etkileri olduğu belirtilmektedir ${ }^{57,15}$. Benzokainin ise uygulama bölgesinde nadiren allerjik kontakt dermatite neden olduğu bildirilmektedir6.

Sonuç olarak, tırnak batması nedeniyle başvuran hastalarda bazal ve palpasyona bağlı ağrı düzeyini azaltmak ve bu şekilde konservatif bir işlem olan tırnak teli uygulamasını yapabilmek amacıyla planlanan çalışmada evre 1 tırnak batmasında bazal ağrının giderilmesinde her iki topikal ajan da eşit şekilde etkili bulunmuş, evre 2 ve 3 olgularda ise benzokain etkili iken lidokain- prilokain mikstürü etkili olmamıştır. Uygulama süresinin kısalığı, uygulanan miktarın azlığı, oklüzyon gerektirmemesi ve etkinliği, ajitasyonu olan, şiddetli ağrı nedeniyle palpasyonu bile tolere edemeyen tırnak batması olgularında \%20 benzokain jelin uygulanabileceğini düşündürmektedir.

Bu çalışmaya ek olarak, tırnak teli aparatı uygulanacak hastalarda uygulama öncesi topikal anesteziklerin etkinliğinin değerlendirilmesi amacıyla plasebo kontrollü daha büyük gruplarda, çeşitlendirilmiş topikal ajanlarla yeni araştırmalar yapılması uygun olacaktır. 


\section{Kaynaklar}

1. Zuber JT: Ingrown toenail removal. Am Fam Physician 2002;65:2547-54.

2. Erdogan FG: A simple, pain-free treatment for ingrown toenails complicated with granulation tissue. Dermatol Surg 2006;32:1388-90.

3. Kocyiğit $P$, Bostancı $S$, Özdemir E, Gürgey E: Sodium hydroxide chemical matricectomy for the treatment of ingrown toenails: comparison of three different application periods. Dermatol Surg 2005;31:744-7.

4. Zuber JT, Pfenninger JL: Management of ingrown toenails. Am Fam Physician 1995;52:181-5.

5. Kaweski S: Topikal anesthetic creams. Plast and Reconstr Surg 2008; 121:2161-5

6. Tulga F, Mutlu Z: Four types of topical anaesthetic agents: evaluation of clinical effectiveness. J Clin Pediatr Dent 1999:23:217-20.

7. Kundu S, Achar S: Principles of office anesthesia: Part 2. Topical anesthesia. Am Fam Physician 2002:66:99-102.

8. Yoon RK, Chussid S: Topical Anesthesia for rubber dam clamp placement in sealant placement: comparison of lidociane/ prilocaine gel and benzocaine. Pediatr Dent 2009;31:377-81.
9. Primosch RE, Rolland-Asensi G: Comparison of topical Emla $5 \%$ oral adhesive to benzocaine $20 \%$ on the pain experienced during palatal anesthetic infiltration in children. Pediatr Dent 2001;23:11-4

10. Nayak R, Sudha P: Evaluation of three topical anaesthetic agents against pain: A clinical study. Indian J Dent Res 2006;17:155-60.

11. Browne J, Fung M, Donnelly $M$, Cooney C: The use of Emla reduces the pain associated with digital ring block for ingrowing toenail correction. Eur J Anaesthesiol 2000;17:182-4.

12. Serour F, Ben-Yehuda Y, Boaz M : Emla cream prior to digital nevre block for ingrown nail surgery does not reduce pain at injection of anaesthetic solution. Acta Anaesthesiol Scand 2002;46:203-6.

13. Eti-Aslan $F$ : Ağrı değerlendirme yöntemleri . C.Ü. Hemşirelik Yüksekokulu Dergisi 2002;6:9-16.

14. Güzeldemir ME: Ağrı değerlendirme yöntemleri. Sendrom 1995;7:11-21.

15. Meechan JG: Effective topical anesthetic agents and techniques. Dent Clin North Am 2002; 46:759-66.

16. Buckley MM, Benfield P: Eutectic lidocaine/prilocaine cream. Drugs 1993;46:126-51.

17. McGee D: Local and topical anesthesia. Clinical procedures in emergency medicine. Ed.Roberts JR, Hedges J. 4'üncü baskı. Philadelphia, WB Saunders, 2004;533-551. 